\title{
Glycogen Synthase Kinase-3 Alpha
}

National Cancer Institute

\section{Source}

National Cancer Institute. Glycogen Synthase Kinase-3 Alpha. NCI Thesaurus. Code

C42621.

Glycogen synthase kinase-3 alpha (483 aa, $51 \mathrm{kDa}$ ) is encoded by the human GSK3A gene. This protein plays a role in protein phosphorylation and signal transduction regulation. 